\title{
ERRATUM
}

\section{Erratum to: Art by Numbers}

\author{
Marco Pierini \\ Direttore della Galleria civica di Modena
}

V. Capecchi (eds.), Applications of Mathematics in Models, Artificial Neural Networks and Arts, DOI 10.1007/978-90-481-8581-8_24, (C) Springer Science+Business Media B.V. 2010

DOI 10.1007/978-90-481-8581-8_28

The contributing author of chapter 24 (Art by Numbers) has mistakenly been interpreted in the chapter opening page as well as the table of contents. The correct contributing author of this chapter is Marco Pierini.

The online version of the original chapter can be found at http://dx.doi.org/10.1007/978-90-481-8581-8_24 